\title{
Research Gaps in Organizational Conflicts: Future Research Perspectives
}

\author{
Ranitha Sachinthana Weerarathna \\ Lecturer \\ Department of Business Management \\ SLIIT Business School \\ Sri Lanka Institute of Information Technology, Malabe, Sri Lanka \\ E-mail: rsachinthana@gmail.com
}

Received: Nov. 13, 2017 Accepted: Nov. 27, 2017 Online published: Nov. 29, 2017

doi:10.5296/ijhrs.v7i4.12214 URL: https://doi.org/10.5296/ijhrs.v7i4.12214

\begin{abstract}
The main objective of this research study was to identify the research gaps in organizational conflicts. Researcher has utilized desk research study to identify three research gaps in organizational conflicts. First research gap can be labeled as there is less empirical evidence on the relationship between organizational conflicts in Sri Lankan and Asian context. Second research gap in this article is known as more studies to analyze the links between organizational conflicts and other affective variables. Third research gap is requirement for more longitudinal studies on organizational conflicts. These research gaps can be utilized by future researchers to conduct their studies on organizational conflicts.
\end{abstract}

Keywords: organizational conflicts, task conflicts, relationship conflicts, research gaps

\section{Introduction}

The concept of organizational conflicts empowered from many academic disciplines. According to Rahim (2001) psychology and philosophy contributed more for organizational conflicts subject area. Organizational conflicts included major theme of occupational psychology/ social psychology as well as organizational behavior (De Dreu, 2008). There is less contribution from science for the developing organizational conflicts subject area. In present context, organizational conflicts are discussed in human resource management and organizational behavior. 


\section{Methodology}

Main objective of this study is to identify research gaps of organizational conflicts. Desk research study method is adopted to achieve the main research objective of this study. Several recognized databases were used to access research articles, such as Sage, Emerald, JSTOR, ScienceDirect and Google Scholar etc. Also researcher used other published books to achieve the research objective of the study.

\section{Literature Review}

\subsection{Organizational Conflicts}

There are many academic disciplines contributed for the study of organizational conflicts. According to Rahim (2001) psychology and philosophy contributed more for organizational conflicts subject area. Organizational conflicts included major theme of occupational psychology/ social psychology as well as organizational behavior (De Dreu, 2008). There is less contribution from science for the developing organizational conflicts subject area. In present context, organizational conflicts are discussed in human resource management and organizational behavior. In addition from theoretical importance, organizational conflicts are important in practical scenario. Contemporary organizations are unable to avoid conflicts in the workplace. And there is no organization without a minor organizational conflict. When there are two parties dealing with any situation, there is a chance for organizational conflicts. Two individual, two groups or organizational units, two organizations and two nations can be included in the major parties in conflicts. It means that organizational conflicts are inevitable situation in any organization.

\subsubsection{Definition of Organizational Conflicts}

There is no clear definition or universally accepted definition for conflicts as different authors defined conflicts in different ways. This is an attempt to identify several definitions of conflicts/ Organizational conflicts and understand important terms in those definitions.

Conflicts can be defined as interactive process that began manifested in incompatibility, disagreement or dissonance within or between individuals, groups, organizations or any other social entity (Rahim, 2001). According to Opatha (2015) definition, conflicts as a disagreement at least between two persons or parties with relevant to important thing which is an interesting thing to both parties. Same author mentioned that conflict can be referred as dispute, fight, struggle or turmoil as well. Afzal (2009) defined conflicts as any disagreement between two or more persons, groups, nations and countries. Finally, Robbins and Judge (2013) stated that conflict is a process that begins when one party perceives that another party has negatively affected, or is about to negatively affects, something that the first party cares about.

Organizational conflicts can be defined as a situation occurs when one employee perceives that his or her interests are negatively affected by another party (Aquino, 2000). Also organizational conflict can be defined as any interaction between workers and clusters with irreconcilable differences or not compatible characters (Rahim, 2001). According to Wall 
and Callister (1995) organizational conflicts can be explained as a situation when individual or group perceives that its goals, values or opinions are being spoiled by interdependent counterpart. Kumar (2009) defined organizational conflicts as a behavior demonstrated by organizational members which is expended in opposition to other members. Same description given by Roloff (1987) for the organizational conflicts. According to him, organizational conflicts incurred when members engage in activities that are incompatible with the other party who utilize the products and services of the organization.

Based on the critical analysis of those above mentioned definitions, common elements can be identified with regard to definition of organizational conflicts. Organizational conflicts are involved with perceptions and beliefs, organizational conflicts can be derived between two individual, groups, departments or two organizations. One Party or both parties interest negatively affected. Rahim (2001) has identified the overlapping areas of most recent definitions of conflicts which are compatible with the researcher's findings. Those are

- Conflicts prevent someone from achieving their goals

- Conflicts linked with beliefs

- Conflicts include opposing interests between individuals and goals.

- Conflicts is a process which has series of steps

\subsection{Reasons for Organizational Conflicts}

As researcher's interest is on organizational conflicts, this section focuses on the reasons or causes for organizational conflicts. According to De Dreu and Gelfand (2007) organizational conflicts can be occurred due to scarcity of productive resources (time, financial budgets, status etc.), values and beliefs of the employees (moral values, religious beliefs and political preferences) or because of insights facts. Organizational conflicts can be aroused when there is an incompatibility, dissatisfaction, arguments, interdependence and mismatch between preferences, values, goals and attitudes between employees in the organization (Cheong and Kim, 2017). On other hand, Robbins and Judge (2013) there are several reasons for organizational conflicts such as communicational issues (inadequate information, semantic differences and differences of backgrounds) and structural issues (goal incompatibility, ambiguity in authority and issues in leadership style) and personal factors (values, beliefs, attitudes and personality issues). Aswathappa and Ready (2009) identified several reasons (sources) for organizational conflicts as inadequate communication, incompatible personalities, unclear job boundaries, unclear policies, unrealistic deadlines and organizational complexities etc.

Sri Lankan organizational behavior researcher Opatha (2015) presented more appropriate classification for the reason for organizational conflicts. According to him, all the reasons for organizational conflicts can be categorized in to two main groups; they are organizational causes and personal reasons. Organizational reasons occurred due to issues in organizational structure and personal reasons can be occurred from the differences among employees. The examples for organizational reasons are competition for scarce resources, goal differences, 
role differences, ambiguous jurisdictions (unclear responsibilities), status differences, dependence of one party, overspecialization. The examples for personal causes are perceptions, domination, greed or avarice, unwillingness to communicate, rudeness and incivility. Causes of conflicts ca visualized by following diagram.

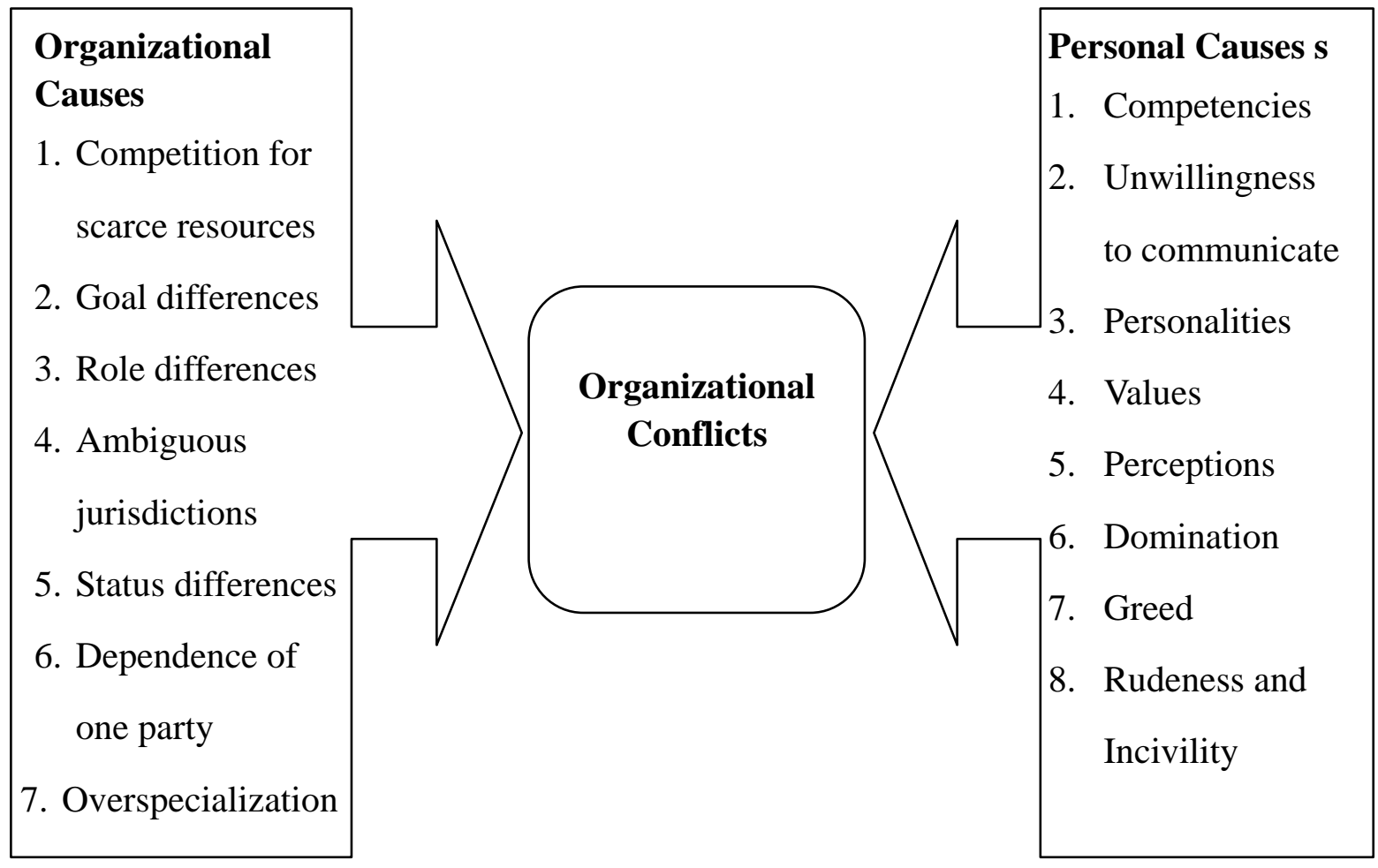

Figure 1. Causes of Organizational Conflicts

Source: Opatha, H.H.D.N.P. (2015), Organizational Behaviour. Colombo: Author Publication.

\subsection{Perspectives / Views of Organizational Conflicts}

Based on the extensive literature review, there are three perspectives or three views of organizational conflicts can be identified. As per traditional perspective, organizational conflicts must be avoided. Later organizational conflicts viewed as natural and not as negative, which has positive to increase the performance of the organization. Finally, researchers have viewed conflicts as a positive force to develop healthy relationships in the organization and perform effectively (Afzal et al., 2009). Robbins and Judge (2013) identified three perspectives of conflicts which are known as traditional view of conflicts, interactionist view of conflicts and resolution focused view of conflicts. According to them, traditional view of conflicts believed that conflicts are harmful to the organizations and must be eliminated. According to interactionist view, conflicts can be treated as a positive force as well there is a necessity to eliminate the conflicts. Robbins and Judge (2013) mentioned that resolution based view of conflict recognized conflicts are inevitable in the organization and organization should focus on more productive conflict resolution. 
Another schools of thought explored that there are three perspectives of organizational conflicts (Vokic and Sontor,2009). They are known as traditional perspective, behavioral perspective and interactionist perspective. Kumar (2009) identified two view conflicts instead of three views. Those are classical view of conflicts and modern view of conflicts, classical view pointed out conflicts are bad and must be avoided at any cost. Modern view of conflicts categorized functional conflicts (those are supported for group performance and organizational performance) and dysfunctional conflicts (those conflicts hinders the group performance and organizational performance). Functional conflicts and dysfunctional conflicts described as follows.

\subsection{Functional and Dysfunctional Conflicts}

Based on the perspectives of conflicts, organizational conflicts can be viewed as two sides of one coin, first side can be taken as functional conflicts. Functional conflicts described as conflicts or disagreement between individuals and groups which support for the achievement of organizational goals and those conflicts helps to increase organizational performance as well as job performance (Opatha, 2015). Kumar (2009) described functional conflicts as confrontation of two different ideas, goals or individuals that help to increase employee performance and organizational performance. Functional conflicts refers as conflicts which supports for the goals of the group and supports for the improvement of the performance of the group (Robbins and judge, 2013). Opatha (2015) identified the positive consequences from functional conflicts as follows. Functional conflicts leads to new ideas and creativity, also those conflicts can lead for new solutions to the problems in the group, those conflicts helps to energize the group members and functional conflicts provide learning opportunity to the group members as well. Kumar (2009) also presented the similar positive consequences of functional conflicts. For example, functional conflicts give second opportunity to the employees to think about the existing situation, it leads to innovation and new direction to the organization and employees can find search behavior due to functional conflicts.

The other side of coin is dysfunctional conflicts. Dysfunctional conflicts can defined as conflicts or disagreement between individuals and groups which do not support for the achievement of organizational goals and those conflicts do not help to increase organizational performance as well as job performance (Opatha, 2015). Kumar (2009) described dysfunctional conflicts as confrontation of two different ideas, goals or individuals that hinders employee performance and organizational performance. Dysfunctional conflicts refers as conflicts which are not supportive for the goals of the group and not supportive for the improvement of the performance of the group (Robbins and Judge, 2013). Opatha (2015) explained the negative consequences of dysfunctional conflicts such as it threatens psychological well-being of employees, it wastes resources, it creates negative climate and it increases hostility and aggressive behaviors of employees. Kumar (2009) mentioned the negative consequences of conflicts or results of dysfunctional conflicts. Those are, dysfunctional conflicts always harmful to the organization because people work against organizational objectives, also it creates distrust and suspicion of the minds of employees, those dysfunctional conflicts create dissatisfaction, low morale, increased labour turnover and decreased productivity. Also it yields less cooperation in future as well. 
This study is an attempt to investigate the relationship of employees' intention to leave from the organization and organizational conflicts which created as a result of dysfunctional conflicts.

\subsection{Levels of Organizational Conflicts / Types of Organizational Conflicts}

Based on literature review from organizational behavior and human resource management, various types and levels of organizational conflicts can be identified. But various authors classified organizational conflicts into different ways. For example, Rahim (2001) classified organizational conflicts into two main levels as intra-organizational conflicts and interorganizational conflicts. Further he has classified intra-organizational conflicts into intrapersonal conflicts, interpersonal conflicts, intragroup conflicts and intergroup conflicts. Kumar (2009) identified four levels of organizational conflicts, namely as intra-individual, inter personal conflict, inter group conflicts, intra-individual conflicts. Aswathappa and Reddy (2008) presented similar classification for levels of conflicts as intra-individual, inter personal conflict; inter group conflicts, intra-groups conflicts.

\subsubsection{Intrapersonal Conflicts and Interpersonal Conflicts}

As per mostly commonly use classification by Rahim (2001), intra-organizational conflict refers as conflicts within the organization and inter-organizational conflicts refers as the conflicts between two different organizations. Further, intra-organizational conflicts into intrapersonal conflicts, interpersonal conflicts, intra-group conflicts and inter group conflicts. Same author described intrapersonal conflicts occurs when individual is unable perform role which does not match with his or her expertise and skills. Interpersonal conflicts occurs between two employees in the same organization.

\subsubsection{Intragroup Conflicts}

Rahim (2001) defined intragroup conflicts as conflicts among two sub groups in the same organization and it is known as interdepartmental conflicts. Intra-group conflicts refer to conflicts which occur within organization, departments to departments, branch with another branch and employee to employee (Anwar et al., 2012). Second definition is different from Rahim (2001) definition. Jehn (1995) identified two types of intragroup conflicts as task conflicts and relationship conflicts. Later, Jehn and Mannix (2001) and De Dreu and Weingart (2003) identified three types of intragroup conflicts as task conflicts, relationship conflicts and process conflicts.

There are three types of intra-group conflicts including task conflicts, relationship conflicts and process conflicts. Task conflicts can be defined as disagreements of view with regard to the task of team (Jehn and Chatman, 2000). Also Jehn (1994) described task conflicts as conflicts of ideas about the content and issues of the task. Riaz and Junaid (2014) mentioned alternative terms for task conflicts as cognitive conflicts and substantive conflicts.

Second type of intragroup conflict is relationship conflicts which known as affective conflicts and emotional conflicts (Riaz and Junaid 2014). Relationship conflicts can be defined as awareness of individuals about the incompatibilities which include affective components of 
individuals (Jehn and Mannix, 2001).In other word, Jehn (1995) defined as differences among group members in personal concerns.

Latest addition to intragroup conflicts is process conflicts. Process conflicts can be defined as awareness of controversies about aspects of how task accomplishment will proceed (Jehn and Mannix, 2001). Jehn and Mannix (2001) mentioned that process conflicts can be occurred due to issues of duty and resource delegation.

\subsubsection{Intergroup Conflicts}

According Rahim (2001), intergroup conflicts can be referred as conflicts between two departments or two organizational units in the same organization. This type of conflict is also known as interdepartmental conflicts.

\subsubsection{Inter-Organizational Conflicts}

According Rahim (2001), inter-organizational conflicts can be referred as conflicts between two different organizations. As present study limited to one organization, inter-organizational conflicts are not focused in the present study. Researcher assumed that inter-organizational conflicts are not influenced for employees' intention to leave.

\subsection{Key Studies on Organizational Conflicts}

There are several key studies on organizational / workplace conflicts which are presented in Table 1.

Table 1. Key Studies on Organizational Conflicts

\begin{tabular}{|c|c|c|c|}
\hline $\mathbf{S} / \mathbf{N}$ & Author & Year & Description/ Findings \\
\hline 01 & Jehn & 1995 & $\begin{array}{l}\text { This study was carried out to find whether conflicts can be } \\
\text { beneficial to the groups. Results of the research showed that } \\
\text { whether conflict was beneficial to the group dependents of structure } \\
\text { of the group, in terms of task type, task interdependence and group } \\
\text { norms. }\end{array}$ \\
\hline 02 & $\begin{array}{l}\text { De Dreu and } \\
\text { Weingart }\end{array}$ & 2003 & $\begin{array}{l}\text { This study was a meta-analysis which intended to find the } \\
\text { association between task conflicts, relationship conflicts, team } \\
\text { member satisfaction and team performance. Results reveled } \\
\text { negative relationships among those variables. }\end{array}$ \\
\hline 03 & $\begin{array}{l}\text { De Wit, Greer } \\
\text { and Jehn }\end{array}$ & 2012 & $\begin{array}{l}\text { Results of this meta-analysis show that task conflict and group } \\
\text { performance were more positively related among studies and the } \\
\text { association between task and relationship conflict was relatively } \\
\text { weak. }\end{array}$ \\
\hline 04 & Medina et al., & 2005 & $\begin{array}{l}\text { The main objective of this study is to evaluate relationship between } \\
\text { intragroup conflicts and employees' affective reactions. Results } \\
\text { reveled that relationship conflicts negatively associated with } \\
\text { affective reactions and task conflict doesn't directly relate to } \\
\text { affective reactions. }\end{array}$ \\
\hline 05 & $\begin{array}{l}\text { Hill, Chenevert } \\
\text { and Poitras }\end{array}$ & 2015 & $\begin{array}{l}\text { This research aims to clarify the relationship between changes in } \\
\text { role ambiguity and turnover intentions. Researchers found that there } \\
\text { is a positive relationship between increases in role ambiguity and } \\
\text { turnover intentions over time is mediated by increases in } \\
\text { relationship conflicts. }\end{array}$ \\
\hline 06 & $\begin{array}{l}\text { Afzal, Khan \& } \\
\text { Ali }\end{array}$ & 2009 & $\begin{array}{l}\text { This study found that relationship conflicts have more negative and } \\
\text { significant relationship with employees' performance. }\end{array}$ \\
\hline 07 & Jehn and Manix & 2001 & $\begin{array}{l}\text { Researchers were able to find that well performed teams } \\
\text { characterized by low but increasing levels of process conflicts, low } \\
\text { level of relationship conflict with a rise near deadlines and } \\
\text { moderate level of task conflicts. }\end{array}$ \\
\hline
\end{tabular}




\section{MInstitute Macrothink $_{\text {Int }}$}

\begin{tabular}{|c|c|c|c|}
\hline 08 & Jehn & 1994 & $\begin{array}{l}\text { This study revealed that emotional conflicts were negatively } \\
\text { associated with group performance and satisfaction, On other hand } \\
\text { task conflicts emotional conflicts were negatively associated with } \\
\text { group performance and satisfaction. }\end{array}$ \\
\hline 09 & $\begin{array}{l}\text { Cisneros } \\
\text { al.,2002 }\end{array}$ & 2002 & $\begin{array}{l}\text { Results of this study illustrated that there is a negative association } \\
\text { between relationship conflicts and employees' affective reactions } \\
\text { and relationship conflicts harms organizational conflicts. Task } \\
\text { conflicts do not affect employees' affective reactions negatively. }\end{array}$ \\
\hline 10 & $\begin{array}{l}\text { Lu, Zhou and } \\
\text { Leung }\end{array}$ & 2011 & $\begin{array}{l}\text { Results supported that task conflicts are positively associated to } \\
\text { innovative behaviors and knowledge sharing behaviors and } \\
\text { relationship conflicts are negatively associated with } \\
\text { individual-directed organizational citizenship behaviors and } \\
\text { knowledge sharing behaviors. }\end{array}$ \\
\hline 11 & $\begin{array}{l}\text { Martinez-Corts } \\
\text { et al.,2011 }\end{array}$ & 2011 & $\begin{array}{l}\text { This study concluded that supervisor support buffers the link } \\
\text { between relationship conflict and job satisfaction while co-worker } \\
\text { support moderates the link between task conflict and job } \\
\text { satisfaction and it also considered that the influence of supervisor } \\
\text { support and relationship conflict is relatively more important for } \\
\text { predicting employees'job satisfaction. }\end{array}$ \\
\hline 12. & $\begin{array}{l}\text { Greer et al., } \\
2012\end{array}$ & 2012 & $\begin{array}{l}\text { Both process conflicts and relationship conflicts are detract to team } \\
\text { functioning and task conflicts are also negative for team } \\
\text { functioning. But negative impact of task conflicts on team } \\
\text { functioning can be minimized in certain situations. }\end{array}$ \\
\hline 13 & Jehn et al.,2006 & 2006 & $\begin{array}{l}\text { This study stated that perceived conflicts asymmetries were } \\
\text { negatively related with work motivation and satisfaction, and } \\
\text { positively related with absenteeism. }\end{array}$ \\
\hline 14 & $\begin{array}{l}\text { Bendersky et } \\
\text { al.,2010 }\end{array}$ & 2010 & $\begin{array}{l}\text { With quantitative and qualitative information, those researchers } \\
\text { presented six dimensional group conflict structure. }\end{array}$ \\
\hline 15 & Shanthakumary & 2012 & $\begin{array}{l}\text { Sri Lankan based research study showed that there is a negative } \\
\text { relationship between relationship conflict and job satisfaction and } \\
\text { positive relationship between relationship conflict and propensity to } \\
\text { leave. Researcher has conducted her survey by using fifty (50) shop } \\
\text { workers in Jaffna district in Sri Lanka. }\end{array}$ \\
\hline 16 & $\begin{array}{l}\text { Weerarathna and } \\
\text { Weerasinghe }\end{array}$ & 2017 & $\begin{array}{l}\text { Researchers found that there is a positive relationship between } \\
\text { organizational conflicts and employees' intention to leave from the } \\
\text { organization. }\end{array}$ \\
\hline 17 & Jehn & 1997 & $\begin{array}{l}\text { Results of this qualitative study revealed that relationship conflicts } \\
\text { detrimental to performance and satisfaction while process conflicts } \\
\text { detrimental to performance. Effects of task conflicts on } \\
\text { performance depend on certain conditions. }\end{array}$ \\
\hline 18 & $\begin{array}{l}\text { Mooney et al., } \\
2007\end{array}$ & 2007 & $\begin{array}{l}\text { This study provided empirical evidence that cognitive (task } \\
\text { conflicts) conflicts unintentionally provoke the affective } \\
\text { (relationship conflicts) conflicts. }\end{array}$ \\
\hline 19 & Khan et al., & 2009 & $\begin{array}{l}\text { Researchers found that there is strong negative relationship between } \\
\text { task conflicts and employee performance. }\end{array}$ \\
\hline 20 & Weerarathna & 2014 & $\begin{array}{l}\text { Results of this study showed that there is positive relationship } \\
\text { between task conflicts and employees' performance and there is a } \\
\text { positive relationship between relationship conflicts and employee } \\
\text { performance. }\end{array}$ \\
\hline 21 & Frone & 2000 & $\begin{array}{l}\text { This study developed a model of interpersonal conflicts and } \\
\text { psychological outcomes of young workers. It predicts that conflict } \\
\text { with supervisors is predictive of organizationally relevant } \\
\text { psychological outcomes (job satisfaction, organizational } \\
\text { commitment, and turnover intentions), whereas conflict with } \\
\text { coworkers is predictive of personally relevant psychological } \\
\text { outcomes (depression, self-esteem, and somatic symptoms). }\end{array}$ \\
\hline 22 & Rukshan et al., & 2016 & $\begin{array}{l}\text { The main objective of this research is to identify the influence of } \\
\text { individualism and collectivism on managing conflicts at work } \\
\text { place. Researchers found that there is a positive moderate } \\
\text { relationship between individualism and conflict management styles } \\
\text { and there is a positive moderate relationship between collectivism } \\
\text { and conflict management style. }\end{array}$ \\
\hline
\end{tabular}




\subsection{Identified Gaps in the Literature of Organizational Conflicts}

Based on the comprehensive literature review and based on the previous studies of organizational conflicts, following research gaps were identified by the researcher.

Gap 01: There is less empirical evidence on the relationship between organizational conflicts in Sri Lankan and Asian context.

Riaz and Junaid (2013) stated that majority of studies of organizational conflicts were conducted in North America or Western countries (individualized countries), less studies were conducted in Asian countries (collectivist countries). In Sri Lankan context, Shanthakumary (2012) found that there is a negative relationship between relationship conflict and job satisfaction and positive relationship between relationship conflict and propensity to leave. It does not support to generalize the findings from North American countries or Western countries. There should be more studies to be conduct to test the association empirically and to generalize the findings from western countries to Asian countries.

Lu et al., (2011) conducted a study to investigate the effects of task and relationship conflicts on individual work behaviors by using one hundred sixty six pairs of supervisors and subordinates of China. Same authors suggested the need of conducting more research studies in Asian countries and Western countries to check the influence of cultural factors on organizational conflicts. Collectivist countries tend to favor for cooperation and try to avoid conflicts than individualist countries (Hofstede, 2001). Tjosvold and Yu (2007) stated that Asian people like to believe that conflicts lead to decreased performance. Although several scholars have emphasized the importance of studying cultural influence on organizational conflicts, it has not been empirically tested in Sri Lankan /Asian context.

Another study was conducted by Chun and Choi (2014) to investigate the relationships between psychological needs of group members, intragroup conflict, and group performance. This study was conducted by using one hundred forty five (145) work teams in sixty three (63) Korean organizations. Chun and Choi (2014) study was based on Korean organizations which come under the collectivist countries. Same authors suggested that more studies from collectivist countries/ Asian countries should be conducted on organizational conflicts/ intragroup conflicts in order to generalize the findings. All these empirical evidence proved that there is less empirical evidence on the relationship between organizational conflicts and other employee related variables in Sri Lankan and Asian context.

Gap 02: More studies to analyze the links between organizational conflicts and other affective variables

De Dreu and Weingart (2003) studied about the association between relationship conflicts, task conflicts, team performance and team member satisfaction. Same authors identified that satisfaction is related to absenteeism, turnover and organizational citizenship behavior and assumed that relationship conflicts are more than task conflicts affects to absenteeism, turnover and organizational citizenship behavior. Medina et al., (2005) conducted a study to evaluate the link between task conflicts and relationship conflicts and their influence on employees' affective reactions (satisfaction, wellbeing and propensity to leave). Same authors 
recommended that future research should study more about the relationship between types of conflicts and other affective variables.

Gap 03: More longitudinal studies on organizational conflicts

Most of previous researchers emphasized that there should be more empirical research studies in future in order to present more strong causal conclusions. Most of previous research studies were conducted as cross sectional studies, except few studies (Jehn and Mannix Study, 2001; Tekleab et al., 2009; Hill et al., 2015; Lira et al.,2008 Gamero et al.,2008 etc.) . There are several researchers pointed out that there should be more longitudinal studies in future. For example Medina et al., (2005) pointed out that task conflicts may be transformed to relationship conflicts in the future which can be counterproductive. Therefore, same researchers suggested that more longitudinal studies required to test the transformation of task conflicts into relationship conflicts. Mooney et al., (2007) presented similar idea. They stated that cognitive conflicts (task conflicts) ignites to affective conflicts (relationship conflicts) future longitudinal studies needed to analyze the transformation of cognitive conflicts (task conflicts) to affective conflicts (relationship conflicts).

Frone (2000) conducted a cross sectional study on interpersonal conflicts at work and psychological outcomes (job satisfaction, organizational commitment and turnover intentions) of young workers and suggested that future longitudinal studies are needed to draw strong causal conclusions on interpersonal conflicts at work and psychological outcomes.

All these empirical evidence proved that there should be more longitudinal studies on organizational conflicts.

\section{Conclusion}

As mentioned above, organizational conflict is an interesting research area in organizational behavior, human resource management and organizational psychology. The main objective of this study is to explore the research gaps in organizational conflicts with the support of comprehensive literature review. Researcher identified three research gaps which can be categorized as empirical gaps and theoretical gaps. Research gap 1 and research gap 3 in this article can be categorized in to empirical gaps in organizational conflicts research area. Research gap 2 in this article can be categorized in to the theoretical gap. This research paper provides useful insights to future researchers to conduct their studies on organizational conflicts.

\section{Reference}

Afzal, H., Khan, M. A., \& Ali, I. (2009). Linkage between employee's performance and relationship conflict in banking scenario, International Journal of Business and Management, 4(7). https://doi.org/10.5539/ijbm.v4n7p19

Anwar, N., Maitlo, Q., Soomro, M. B., \& Shaikh, G. M. (2012). Task Conflicts and its Relationship with Employee's Performance. Interdisciplinary Journal of Contemporary Research in Business, 3(9). 
Aquino, K. (2000). Structural and Individual Determinants of Workplace Victimization: The Effects of Hierarchical Status and Conflict Management Style. Journal of Management, 26(2), 171-193. https://doi.org/10.1177/014920630002600201

Aswathappa, K., \& Reddy, G. (2009). Organisational behaviour (1st ed.). Mumbai [India]: Himalaya Pub. House.

Bendersky, C., Behfar, K., Weingart, L., Todorova, G., Bear, J., \& Jehn, K. (2010). Revisiting the Dimensions of Intra-group Conflict: Theoretical and Psychometric Construct Refinement. PsycEXTRA Dataset. https://doi.org/10.1037/e673512012-008

Cheong, J., \& Kim, C. (2017). Determinants of Performance in Government: Focusing on the Effect of Organizational Politics and Conflicts in Organizations. International Journal of Public Administration, 1-13. https://doi.org/10.1080/01900692.2017.1280818

Chun, J., \& Choi, J. (2014). Members' needs, intragroup conflict, and group performance. Journal of Applied Psychology, 99(3), 437-450. https://doi.org/10.1037/a0036363

Cisneros, I. F., Dorado, M. Á, Martinez, I., Medina, F. J., \& Jaca, L. M. (2002). Types of Conflict and Personal and Organizational Consequences. SSRN Electronic Journal.

De Dreu, C. K. W. (2008). The virtue and vice of workplace conflict: Food for (pessimistic) thought, Journal of Organizational Behavior, 29(1), 5-18. https://doi.org/10.1002/job.474

De Dreu, C. K. W., \& Gelfand, M. J. (Eds.). (2008). The psychology of conflict and conflict management in organizations. New York, NY: Erlbaum.

De Dreu, C., \& Weingart, L. (2003). Task versus relationship conflict, team performance, and team member satisfaction: A meta-analysis. Journal of Applied Psychology, 88(4), 741-749. https://doi.org/10.1037/0021-9010.88.4.741

De Wit, F., Greer, L., \& Jehn, K. (2012). The paradox of intragroup conflict: A meta-analysis. Journal of Applied Psychology, 97(2), 360-390. https://doi.org/10.1037/a0024844

Frone, M. (2000). Interpersonal conflict at work and psychological outcomes: Testing a model among young workers. Journal of Occupational Health Psychology, 5(2), 246-255. https://doi.org/10.1037/1076-8998.5.2.246

Gamero, N., González, R. V., \& Peiró, J. M. (2008). The influence of intra-team conflict on work teams affective climate: A longitudinal study. Journal of Occupational and Organizational Psychology, 81(1), 47-69. https://doi.org/10.1348/096317907X180441

Greer, L. L., Saygi, O., Aaldering, H., \& Dreu, C. K. (2012). Conflict in medical teams: $\begin{array}{llll}\text { opportunity } & \text { or } \quad \text { danger? Medical } & \text { Education, 46(10), }\end{array}$ https://doi.org/10.1111/j.1365-2923.2012.04321.x

Hill, K., Chênevert, D., \& Poitras, J. (2015). Changes in relationship conflict as a mediator of the longitudinal relationship between changes in role ambiguity and turnover 
intentions. International Journal of Conflict Management, 26(1), 44-67. https://doi.org/10.1108/IJCMA-11-2013-0091

Inés, M., Marina, B., Francisco, J. M., Miriam, B., \& Lourdes, M. (2011). Coping with Interpersonal Conflict at Work in Small Business: The Moderating Role of Supervisor and Co-Worker Support. Revista de Psicología del Trabajo y de las Organizaciones, 27(2), 117-129. https://doi.org/10.5093/tr2011v27n2a4

Jehn, K. (1994). Enhancing Effectiveness: An Investigation of Advantages and Disadvantages of Value-Based Intragroup Conflict. International Journal of Conflict Management, 5(3), 223-238. https://doi.org/10.1108/eb022744

Jehn, K. (1995). A Multimethod Examination of the Benefits and Detriments of Intragroup Conflict. Administrative Science Quarterly, 40(2), 256. https://doi.org/10.2307/2393638

Jehn, K. (1997). A Qualitative Analysis of Conflict Types and Dimensions in Organizational Groups. Administrative Science Quarterly, 42(3), p.530. https://doi.org/10.2307/2393737

Jehn, K., \& Mannix, E. (2001). THE DYNAMIC NATURE OF CONFLICT: A LONGITUDINAL STUDY OF INTRAGROUP CONFLICT AND GROUP $\begin{array}{llll}\text { PERFORMANCE. Academy } & \text { Of } \quad \text { Management } & \text { Journal, 44(2), } 238-251 .\end{array}$ https://doi.org/10.2307/3069453

Jehn, K., Northcraft, G., \& Neale, M. (1999). Why Differences Make a Difference: A Field Study of Diversity, Conflict, and Performance in Workgroups. Administrative Science Quarterly, 44(4), 741. https://doi.org/10.2307/2667054

Jehn, K., Rupert, J., \& Nauta, A. (2006). The effects of conflict asymmetry on mediation outcomes. International Journal of Conflict Management, 17(2), 96-109. https://doi.org/10.1108/10444060610736594

Kumar, N. (2009). Organizational Behaviour : A New Look: Concept, Theory \& Cases. Himalaya Pub. House.

Lira, E. M., Ripoll, P., Peiró, J. M., \& Orengo, V. (2008). How do different types of intragroup conflict affect group potency in virtual compared with face-to-face teams? A longitudinal study. Behaviour \& Information Technology, 27(2), 107-114. https://doi.org/10.1080/01449290600875151

Lu, L., Zhou, F., \& Leung, K. (2011). Effects of task and relationship conflicts on individual work behaviors. International Journal of Conflict Management,22(2), 131-150. https://doi.org/10.1108/10444061111126675

Medina, F., Munduate, L., Dorado, M., Martínez, I., \& Guerra, J. (2005). Types of intragroup conflict and affective reactions. Journal of Managerial Psychology, 20(3/4), 219-230. https://doi.org/10.1108/02683940510589019

Mooney, A. C., Holahan, P. J., \& Amason, A. C. (2007). Dont Take It Personally: Exploring Cognitive Conflict as a Mediator of Affective Conflict. Journal of Management Studies, 44(5), 733-758. https://doi.org/10.1111/j.1467-6486.2006.00674.x 
Opatha, H. H. D. N. P. (2015). Organizational Behaviour. Colombo: Author Publication.

Rahim, A. M. (2001). Managing conflict in organizations. 3rd edn. United States: Quorum Books,U.S.

Riaz, M. K., \& Junaid, F. A. (2013). Workplace Conflict: Constructive or Destructive. SSRN Electronic Journal. https://doi.org/10.2139/ssrn.2247886

Robbins, S., \& Judge, T. (2013). Organisational behaviour (13th ed.). Cape Town, [South Africa]: Pearson Holdings Southern Africa

Rukshan, W., Nishanthi, H., \& Mahalekamge, W. (2014). Impact of Individualism and Collectivism on Managing Conflicts at Work: Evidence from Public Sector Banks in Sri Lanka. Kelaniya Journal of Human Resource Management, 9(1-2), 49. https://doi.org/10.4038/kjhrm.v9i1-2.12

Shanthakumary, M. A. (2012). The Effect of Conflict On Propensity To Leave And Job Satisfaction Among Shop Workers. First Annual Research Conference. Oluvil

Tekleab, A. G., Quigley, N. R., \& Tesluk, P. E. (2009). A Longitudinal Study of Team Conflict, Conflict Management, Cohesion, and Team Effectiveness. Group \& Organization Management, 34(2), 170-205. https://doi.org/10.1177/1059601108331218

Tjosvold, D., \& Yu, Z. (2007). Group Risk Taking. Group \& Organization Management, 32(6), 653-674. https://doi.org/10.1177/1059601106287110

Vokic, N., \& Sontor, S. (2009). Conflict Management Styles in Croatian Enterprises - The Relationship between Individual Characteristics and Conflict Handling Styles. FEB Working Paper Series.

Wall, J., \& Callister, R. (1995). Conflict and its management. Journal Of Management, 21(3), 515-558. https://doi.org/10.1177/014920639502100306

Weerarathna, R. S. (2014).The Relationship between Conflicts and Employee Performance. International Journal of Scientific and Engineering Research, 5(5), 1270-1277.

Weerarathna, R., \& Weerasinghe, I. (2017). A Study of the Relationship between Organizational Conflicts \& Employees' Intention to Leave with Special Reference to Staff Assistants in ABC Merchant Bank of Sri Lanka. Global Journal of Management and Business Research: An Administration and Management, 17(4), 43-58.

\section{Copyright Disclaimer}

Copyright for this article is retained by the author(s), with first publication rights granted to the journal.

This is an open-access article distributed under the terms and conditions of the Creative Commons Attribution license (http://creativecommons.org/licenses/by/4.0/). 